\title{
Mental Toughness as Character Required in Learning in the Age of Change
}

\author{
Arcadius Benawa ${ }^{1 *}$ and Benny ${ }^{2}$ \\ ${ }^{1}$ Faculty of Economics \& Communication, Bina Nusantara University, Jakarta \\ ${ }^{2}$ School of Computer Science, Bina Nusantara University, Jakarta \\ *Corresponding author email: aribenawa@,binus.ac.id
}

\begin{abstract}
The purpose of this paper is to show that distance learning motivates and inspires the students. Distance learning showed the enthusiasm of the students, with their active participation to ask, answer, and share experiences about their mental toughness as students. The conclusion of this research has several implications. First, the students to be more aware of the importance of mental toughness in carrying out their duties as students who still have a long way ahead to achieve their ideals. Second, the spirit of teachers in assisting students in the age of change massively affects the character development of students. Third, the totality of the parents of students to pay more attention to their children who still need parental assistance so they can have more personal resiliency.
\end{abstract}

Keywords: Mental, Character, Learning

\section{INTRODUCTION}

The age of change has been felt a long time ago. For example, in the Book of Ecclesiastes [1] it has been confirmed that under the sun there is nothing new. The preacher's expression indicates that change continues to occur in all sides of life, including in the world of education. Changes in the world of education cannot be separated from the influence of the development of the education mindset itself and the impact of the development of technology. This can be traced to the opinion of Sir Asbhy [2] who put forward the educational revolution.

The age of change due to the development of technology also has an impact on social interactions between people. McLuhan [3] even termed a big village for the world thanks to the rapid development of technology. Global Village is a condition regarding the development of communication technology where the world can be analogous to being a very large and extensive village. Marshall McLuhan introduced this concept in the early '60s in the writings of his book Understanding Media: Extension of A Man.

Meanwhile, Thomas L. Friedman [4] used the term world is flat. As if in a flat place, everything is easily known, nothing is hidden. Thomas L. Friedman argued globalization at the beginning of the 21 st century. The title of his book The World Is Flat: A Brief History of the Twenty-First Century is his point of view that the world is an equal playing field in the trade sector, where all competitors have equal opportunities. He also noted that changing perceptions is needed for countries, companies, and individuals to continue to compete in the global marketplace when historical and geographic differences become less important.

Some years later, Anthony Giddens [5] revealed that today we are living in a world that is running fast. It was a risk that anyone who didn't run would inevitably fall far behind. In such conditions, it is as if humans only live to complete their desires, without paying attention to existing limitations, whether those are moral, social, or even divine values. The point is that he can still balance his left and right in order not to be left behind in all matters, especially the achievements related to information, science and technology. In the era of such rapid changes, Giddens emerge terminology of Violability, Uncertainty, Complexity, and Ambiguity (VUCA).

In the current pace of change, it is exacerbated by the emergence of the coronavirus disease (COVID19) which has spread to since early 2020 . With the spread of the Covid 19 which has become a pandemic affecting the joints of life as a whole, including in the world of education, so that learning which is usually held face-to-face is no longer possible and must be held online. It is fortunate that the technology that continues to develop at rapid pace help to overcome this rapidly changing difficulty, so like it or not distance learning must be done because everyone has to work from home and learn from home. Therefore, in addition to the need for many devices related to learning facilities and infrastructure, teachers and students are required to have mental toughness as a character that is required in learning in the age of change. The reason is, to be 
able to adapt in an era of rapid change like now is impossible without mental toughness both for students and teachers in the learning process.

\section{LITERATURES REVIEW}

In this section of the literature review, four things will be highlighted in this article, namely regarding the age of change, learning that occurs in the age of change, particularly learning that must take place in the age of change hit by coronavirus disease (COVID-19) pandemic; mental toughness; and the character which required as an implication of the age of change.

\subsection{The age of change}

Sir Isac Rabby, as cited by Miarso, explained that there were four revolutions in education [6]. In this context, the first revolution takes place when a parent or family leaves some of its educational responsibility to someone else who is individually responsible for it. For example, the Sufis who are in about 500 BC became 'the sellers of knowledge' to anyone willing to give them wages or rewards. The second revolution occurred when the teacher as an individual was overwhelmed with the responsibility to educate. Teaching was performed verbally and orally, and educator activities began to be institutionalized with various standardized provisions. At this point, the first revolution cannot be identified when such a second revolution takes place. However, it is acceptable that it was undergoing the process. The third revolution emerged with the invention of the printing press, which allowed the dissemination of iconic and numeric information in the form of books or other print media. With this in mind, the book is considered as the foremost media in addition to teachers for educational purposes. This revolution is still going on, so there is an expression that the learning community is a reading society. The fourth revolution took place with the rapid development in the field of electronic communication media. In this case, the most prominent factor is social media, such as radio, television, and tape that successfully penetrate the geographical, social, and political boundaries more intensely than the printed media.

\subsection{Learning}

There are many theories about learning. Among other things, as Gregory A. Kimble [7] stated that learning is a relatively permanent change in behaviour or potential behaviour that comes from experience and cannot be attributed to temporary body states such as conditions caused by illness, fatigue, or drugs. Meanwhile, according to Gagne and Briggs [8], learning is a system that aims to assist the student learning process, which contains a series of events designed, arranged in such a way as to influence and support the internal student learning process. Then Dimyati and Mudjiono [9] by accommodating the views of Skinner, Gagne, and Piaget, and Rogers concluded that learning is a complex behaviour in individuals in interactions between students and teachers that aim to. Dynamic learning occurs by learning actors and the learning environment. The teacher's effort to dynamize learning is related to the readiness of students to face learning materials, creating a pleasant learning atmosphere, optimizing media and learning resources, and maximizing the role of learners.

Referring to the article of Irfan Kamil [10] which title "Flashback of Distance Learning due to the COVID-19 Pandemic" revealed that currently the whole world is being hit by the Coronavirus disease (Covid-19) Pandemic, including in Indonesia, faceto-face teaching and learning activities in schools have to be stopped. The goal is to prevent Covid-19 from spreading. The government through the Ministry of Education and Culture decided to move the learning space into cyberspace. This program is known as Distance Learning. Students should be able to use internet devices and networks to get learning materials from teachers at school.

Minister of Education and Culture Nadiem Makarim issued a circular for the prevention of the coronavirus disease (COVID-19) in the education unit. The letter dated $9 / 3 / 2020$ is addressed to heads of provincial education offices, heads of district/city education offices, heads of higher education service institutions, leaders of higher education institutions, and principals throughout Indonesia. Nadiem Makarim invited various parties in the world of education to move together to face the coronavirus which has been officially designated by WHO as a global pandemic to take steps to prevent the spread of COVID-19 in the educational unit. There have been at least two circular letters issued by the Ministry of Education and Culture regarding the coronavirus: First, Letter Number 2 of 2020 concerning the Prevention and Handling of COVID19 within the Ministry of Education and Culture. Second, Circular Number 3 of 2020 concerning Prevention of Covid-19 in the Education Unit. School activities also took place unlike in previous years, during the situation before the coronavirus pandemic. However, various challenges must be faced for the continuity of education in this country. The problems that must be faced are mainly related to infrastructures, such as electricity and internet networks. In addition, there are many families who 
do not have gadgets to participate in distance learning. Internet network is a problem. The Indonesian Child Protection Commission (KPAI) received 213 complaints of distance learning, over a period of three weeks, from March 16 to April 9, 2020. The majority of complaints were related to the severity of assignments given by teachers to students.

In addition, the National Coordinator for the Indonesian Education Monitoring Network, Ubaid Matarji, assessed that the concept of distance learning is still difficult to implement at this time. According to Ubaid, both human resources and technology are considered not yet supporting the application of distance learning. Another need supporting infrastructure, namely the internet. Many areas outside Java Island do not yet have internet infrastructure, especially in the underdeveloped, frontier, and outermost areas. However, distance learning has its own challenges that must be faced. Therefore, the teachers' creativity is very needed in its implementation. So, they have to get out of the conventional style. They are also required to be more innovative in preparing materials and learning mechanisms. Including utilizing all the potential of existing technology to assist the implementation of learning.

\subsection{Character}

Kupperman [11] explained that character is a normal pattern of thought and action, especially with respect to concerns and commitments in matters affecting the happiness of others or self, and most especially in relation to moral choices.

Meanwhile, according to Wynne [12] revealed that character is a sign of how to focus on how to apply the value of goodness in the form of actions or behaviour. Therefore, someone who behaves dishonestly, cruelly or greedily is said to be a person with ugly character, while someone who behaves honestly, likes to help is said to be someone with a noble character. So, the term character is closely related to a person's personality. How does anyone apply the value of goodness in the form of actions or behaviour, because if someone has good ethical attitudes, it means that person has a noble character. Conversely, if someone does not have good character, it means that it can be said to be a person who has bad behaviour.

According to the Big Indonesian Dictionary (KBBI) [13], character means 1) Psychiatric, moral or ethical qualities that distinguish a person from others. 2) Characters can also mean "letters".

Meanwhile, according to (Ditjen Mandikdasmen - Ministry of National Education), as argued Thomas
Lickona [14] character is a way of thinking and behaving that characterizes each individual to live and work together, both within the sphere of family, society, nation and state. Individuals with good character are individuals who can make decisions and are ready to take responsibility for any consequences of the decisions they make. Our character is formed from our habits. Our habits as children usually persist into adolescence. Parents can influence good or bad, forming habits of their children.

\subsection{Mental Toughness}

Stoltz [15] discovered a term called "Mental Intelligent" or "Adversity Quotient" that demonstrates the level of success is determined by a person's mental in solving difficulties, obstacles, and failures, which were named as adversity, to achieve success in life. Stoltz explained that Adversity Intelligence is a person's ability to overcome life's difficulties. So, Adversity Intelligence is the ability of people to face life's problems. Mental intelligence represents the mental toughness in overcoming adversity. In this spectrum, the climber mental type is needed in the era of disruption to overcome adversity. Camper's psychological type is not enough, moreover, quitter psychic type.

\section{RESEARCH METHOD}

This research used the method of phenomenological and literature studies that underscore the situation in the age of change with the challenges to whoever in overcoming the circumstance in this era and then exhibit that the person who has mental toughness will survive in the age of change because mental toughness is indeed the characters, which required in learning in the age of change.

\section{RESULT AND DISCUSSION}

From the description of the literature review above, some results can be highlighted for later discussion to obtain solutions.

\subsection{Result}

Some of the results that can be underlined are that there are changes that are so fast nowadays as a result of the development of technology and information so that people have to run fast so as not to fall behind and be able to adapt, considering that this rapidly changing era is marked by the existence of Violability, Uncertainty, Complexity, and Ambiguity (VUCA). No exception in the world of education, change is more felt by the coronavirus pandemic so that the learning system requires fulfillment of numerous prerequisites for effective 
learning to run through a distance learning system during a pandemic. In addition to the problems of learning facilities and infrastructure such as the availability of electricity, internet networks, and computer devices that support learning such as zoom, google meet, microsoft teams, and so on, mental toughness is also needed as a compulsory character in the age of change. Without mental toughness, students and teachers will easily fall into despair when facing many obstacles in the learning process during this pandemic.

\subsection{Discussion}

The sudden change to distance learning due to the pandemic put great confusion to teachers and students. Infrastructure readiness was the main hurdle in implementing distance learning. Big cities can adapt fast due to better infrastructure and access. In remote areas where infrastructure is not adequate, creativity and resourcefulness will provide alternative solutions. A strong mentality will keep the head clear and focused on the use of available resources to solve the issue faced. Gununglurah village in Banyumas is one of the areas with limited infrastructure and minimum internet access area [16]. Schools in Gununglurah are conducting on-air distance learning with walkie-talkie devices. This technology is readily available, cheap, and cover long distances. This ingenuity is impossible without mental toughness from locals.

Mentality wise, teachers and students are facing high walls. Face to face teaching-learning environment provides direct response and the presence of others in the process. By switching to distance learning, it lost human touch and a sense of companionship. Teachers and students are faced with a small screen where it can barely fit all in it. Teachers are focus on materials on-screen and unable to see students body language of students as a direct response to the process. Students feel protected by the computer screen. Attention and focus are hard to maintain due to the small area of the screen compared to other external stimuli. This situation is difficult for everyone. To keep on going and be able to adapt depends on their mental toughness. Adversities bring everyone down on their knees, but mental toughness brings them up on their feet again to keep ongoing.

This pandemic may reflect how ready we are for a sudden change in how we live and particularly in teaching-learning activities. Even though this kind of abrupt change is not going to happen very often, but many things are changing at an accelerated pace. To get the current generation and next-generation ready is almost impossible and resource-wise is expensive.
Strengthening mentally thru mental toughness character is reasonable and not just useful for facing changes in the age of change but to withstand many life adversities as well.

With the recent development of COVID-19 vaccines, the pandemic is not slowing down at all [17]. Vaccination requires a lot of effort and time. There is no guarantee that the developed vaccines eliminate the pandemic. The future is still uncertain, and with recent findings on mutating the COVID-19 that obscures even more. Precaution will always in place to prevent the worst case. Distance learning still will be preferred for face-to-face activities at school in near future. To improve the outcome of distance learning, developing the mental toughness of students should be the main focus of schools. Building character is not an easy feat. Requires changing student's paradigm on how to see and react appropriately. To do that, schools can allocate full time to do that in a boot camp type session.

If the pandemic ends sooner, the mental toughness built on students won't go waste. This character will bring the best out of students, not just in adversities, but they will have the capacity to cope with changes. Students will be ready for the next major change due to disaster, pandemic, or a sudden shift in technology that revolutionizes human life. It was inline with the what Benawa [18] argued that only person who has personal toughness can survive in disruption era. The implication of Benawa's study emphasizes that whoever wants to survive in the disruption era must build his/her own toughness like striving for excellence, perseverance, integrity, respect, innovative, and team-work eventually.

\section{CONCLUSIONS}

Even though distance learning has many disadvantages, with Mental Toughness as a Character to Learn in the Age of Change, distance learning able to have the enthusiasm of students. With enthusiasm, surely students have more involvement by raising questions and engaged in discussions.

\section{IMPLICATIONS}

The conclusion of this learning outcome has several implications.

\subsection{For the students}

First, the students to be more aware of the importance of mental toughness for them in carrying out their duties as students who still have a long way to go in achieving the ideals of a future full of changes with all its consequences. 


\subsection{For the teachers}

Second, the spirit of teachers in assisting students in the age of change massively affect the character development of students.

\subsection{For the parents}

Third, the totality of the parents of students to pay more attention to their children who still need parental assistance so they can have more mental toughness.

\section{ACKNOWLEDGMENTS}

Authors wishing to acknowledge encouragement from Character Building Development Center (CBDC) and Research Technological Transfer Office (RTTO) of Bina Nusantara University, Jakarta.

\section{REFERENCES}

[1] Book of Ecclesiastes p 9

[2] Miarso Yusufhadi 2007 Menyemai Benih Teknologi Pendidikan (Jakarta: Kencana) p 126

[3] McLuhan 1962 Understanding Media: Extension of A Man p 36

[4] Thomas L. Friedman 2005 The World Is Flat: A Brief History of the Twenty-First Century

[5] Anthony Giddens 2009 The Politics of Climate Change (Cambridge: Polity) pp 183-184

[6] Miarso Yusufhadi 2007 Menyemai Benih Teknologi Pendidikan (Jakarta: Kencana) p 126

[7] Gregory A. Kimble 1961 Hilgard and Marquis' conditioning and learning (Englewood Cliffs

New York: Prentice Hall)

[8] Gagne RM \& Briggs L J 1979 Principle of Instructional Design (New York: Holt Rinehart and Winston) p 3

[9] Dimyati \& Mudjiono 2006 Belajar dan Pembelajaran (Jakarta: Rineka Cipta) pp 38-39

[8] Thomas Lickona 2012 Education for Character: How Our School Can Teach Respect and Responsibility (New York: Bantam Books) p 50

[9] Stoltz P G 1997 Adversity Quotient: Turning Obstacles into Opportunities (New York: John

Wiley and Sons)
[10] Kamil I 2020 Kilas Balik Pembelajaran Jarak Jauh akibat Pandemi Covid-19. [Online]. Available: https://nasional.kompas.com/read/2020/09/ 03/10063201/kilas-balik-pembelajaranjarak-jauh-akibat-pandemi

[11] Kupperman J J 1971 Character (New York: Oxford University Press) p 17

[12] Wynne E A 2015 Balancing: Character Development and Academics in the Elementary School The Phi Delta Kappan 697 pp 424-426

[13] KBBI [Online] Available: https://kbbi.web.id/karakter

[14] Thomas Lickona 2012 Education for Character: How Our School Can Teach Respect and Responsibility (New York: Bantam Books) p 50

[15] Stoltz P G 1997 Adversity Quotient: Turning Obstacles into Opportunities (New York: John

Wiley and Sons)

[16] Dirgantara R A 2020 Belajar Pakai HT di Pegunungan Banyumas Jadi Model Pembelajaran untuk Daerah Pelosok [Online] Available: https://www.liputan6.com/regional/read/43 32148/belajar-pakai-ht-di-pegununganbanyumas-jadi-model-pembelajaranuntuk-daerah-pelosok

[17] COVID-19 Explorer [Online] Available: https://worldhealthorg.shinyapps.io/covid/

[18] Benawa A 2020 Personal Toughness as Relevance Character In Disruption Era International Journal of Advanced Science and Technology 29 4s pp 1658-1662 